\title{
Library usage pattern of school teachers in Sri Lanka: problems and issues
}

\author{
C. Gunasekera ${ }^{1}$, R. Balasubramani ${ }^{2}$
}

\begin{abstract}
The aim of the study was to explore Sri Lankan school teachers' information seeking behavior, intention and occasions of accessing libraries, and to measure library skills and the challenges and barriers that they faced during library use. It further examined whether there were any association between the extent of library awareness skills of teachers and four variables such as gender, age, work experience and school locations. A simple random sampling technique was applied to draw the sample for the study and 400 school teachers who had followed postgraduate courses in education were selected as sample from total population (106,756). A questionnaire survey method was used to collect data. Data analysis was done by means of simple and inferential statistics by using SPSS Statistical Package. The results emerged from the present study showed that the studied sample did not regularly access the libraries and they were uncertain about their abilities for effective library use. It was further found that the respondents were rather unsatisfied about the weak library collections of school libraries and improper library services and library arrangements. Unavailability up to date electronic materials and proper guidance also made barriers for school teachers' library use. The analysis further found that there was no association between library awareness skills of the teachers and the four given variables (gender, age, work experience and school location).
\end{abstract}

Keywords: library use, library skills, information seeking behavior, school teachers in Sri Lanka, user studies

1 Senior Assistant Librarian, Main Library, University of Peradeniya, Sri Lanka.

Email: chamanig@yahoo.com, (D) https://orcid.org/0000-0002-8061-4664

2 Assistant Professor, Department of Library and Information Science, Bharathidasan University, Tiruchirappali, India, Email: lisbala@gmail.com 


\section{Introduction}

School libraries are precious sources of information that contribute to productive educational achievement (CILIP, 2004). They are imperative supplement to education as well as a base for generating creative thinking, cultural improvement and for self-development of a person (Önal, 2009). The school library, therefore, is an essential institution for the learning society that helps teachers and students in achieving educational goals. The school library also has full potential to improve the quality of educational processes in a school since it provides knowledge and skills for students and teachers (De la Vega \& Puente, 2010).

Today, most of the resources that relevant to the 'teaching ' can be obtained in digital form and - as a result - users are changing their habits as they do not need to come to physical library for getting information (Hiller, 2002). The physical library has become a student-dominated place and the usage of the physical library by the teachers has declined dramatically since the mid1990s (Martell, 2008). Thus, an investigation needs to be done to determine the factors that caused for low library use of school teachers.

On the other hand, it is believed that school teachers are the key players in successful education and their teaching and learning can be enhanced by establishing functional library with professionally qualified librarians (Wessels \& Mnkeni-Saurombe, 2012). Therefore it is a prime necessity to conduct studies to examine school teachers' library usage, their satisfaction towards library services, their library skills and problems that they faced while using libraries. The findings of such studies will be certainly helpful to identify the factors that affect teachers' library use and consequently they may be helpful to plan and organize more customer focused school libraries for the betterment of school education of the country.

Moreover, the library needs to continue working on users' information needs because users' needs are getting change continuously (Song, 2009). The understanding of users' information needs and the level of their satisfaction towards the library services will be helpful to improve the library services to keep up with upgraded information systems in a digital age with limited funding. Therefore the present study will explore the nature of library use by 
school teachers and also the challenges faced by them when using libraries to fulfill their information needs. This study can successfully be used to develop new policies in relation to school libraries and their services. This in return will help the school libraries to provide a better and effective information service for the teachers by upgrading library services that is an imperative need for the quality education in a country.

\section{Research Objectives}

The main objective of this study is to examine library usage patterns of school teachers in Sri Lanka and to identify the reasons that they prevent from using school libraries, their services and resources effectively. The specific objectives of the study are as follows:

i. To examine the purpose and frequency of library use by the teachers

ii. To assess the level of user satisfaction towards the library services and resources

iii. To identify the problems faced by the teachers when using school libraries

iv. To find out any associations between the extent of library awareness skills of teachers and selected variables

\section{Literature Review}

Although a substantial amount of research literature is available globally on the role and importance of school libraries in education, a limited number of studies have been conducted to examine the role of the school library in delivering school curriculum (Sim, 2001; Tan, 2003) and the extent of its use by teachers. Mokhtar and Majid (2005) found that teachers in Singapore did not use school libraries effectively s. In consistent with these studies Williams and Coles (2007) found that teachers had perceived the school library as a resource for pupils and not for their own professional development. They further found that the lack of time and lack of access to research information in the school library as significant barriers for the school teachers' information gathering. In a study conducted by TachieDonkor and Dadzie (2017) found that secondary school teachers in Ghana had used school libraries to supplement their teaching notes on a topic or subject to be taught in schools and to keep abreast with current information 
in their subject areas. However, most of them claimed that materials available in school libraries were not relevant for their teaching.

A similar study conducted by Korobili et al., (2011) among public secondary schools in Greece found that most of the teachers preferred using their personal collection rather than the library collection because the library did not comprise relevant materials that could help them in developing curriculum. The study further found that teachers did not have the requisite skills that needed to browse the library's collections. Asselin and Doiren, (2003) noted that school library programs were not included in the training of pre-service teachers. As a result, most of the teachers were unable to develop adequate skills for effective school library use. Another study by McLelland and Crawford (2004) revealed that the school library was seriously under-utilized by teaches as a result of limited staff.

Although there are many studies on school library usage of learners, there is little evidence of research on library usage of school teachers in Sri Lanka. In the Sri Lankan context, only one study was found on a similar topic. The study conducted by Rathnayake (2013) found that most of the teachers visited the library to find information that was relevant for the subjects that they taught in the schools. In addition, they used school libraries for reading newspapers (32\%) and referring curriculum related materials (28\%) such as syllabi and teacher's guides etc. The study further revealed that school libraries helped teachers by providing supplementary reading materials that is relevant for teaching. Out of total, $76 \%$ respondents mentioned that the library helped teachers by providing required materials for their professional development as well. With regard to the frequency of library use, the majority (72\%) visited the library when the need arose and $20 \%$ visited once a week which gave an evidence of poor library usage of teachers. It was further evident from the study that the lack of time and heavy work load as main problems encountered by the teachers when using libraries.

\section{Methodology}

The participants who took part in this study were all in- service graduate teachers who followed postgraduate courses at the Department of Education, University of Peradeniya which is one of the main higher educational 
institutions in Kandy district. The total population of graduate school teachers who work in government schools in Sri Lanka is 106,756 (Statistical Abstract, 2017). Based on sample size calculation prescribed by Krejcie and Morgan (1970), 400 were determined as the sample of the present study from the above population $(106,756)$.

A specifically designed self-administered questionnaire (printed version) was used as the main data collection tool and 400 questionnaires were distributed randomly among the participants at their lecture halls in early September 2018. The collected data were analyzed by using SPSS software package (version 21.0).

\section{Results and Discussion}

As mentioned earlier, 400 questionnaires were distributed among the sample and 318 returned resulting $79.5 \%$ response rate.

\section{Personal characteristics of the respondents}

As it can be gleaned from the Table 1, the majority of the sample $(88 \%$,) was female and male comprised only $12 \%$. With regard the age of the respondents, majority were 31- 40 years of age group, with the remainder being between 20-30 (20\%) or 41-50 (19.5\%) years. More than half of the respondents engaged in teaching profession for 1-5 years. Teachers who had been in the profession for 6-10 years made up 23.6\% of the sample, followed by more than ten years( $23.9 \%$ ). With regard to the area of school located, more than one third of the respondents, 125 (39\%) indicated that their schools were situated in a suburb area followed by $35 \%$ in rural area and $24 \%$ in a central city. The schools where the respondents taught were fairly represented town areas as well as rural areas.

Table 1. Personal characteristics of the respondents

\begin{tabular}{llrr}
\hline & Characteristics & Frequency & \% \\
\hline $\mathbf{1}$ & Gender & & \\
& Male & 39 & 12.3 \\
& Female & 279 & 87.7 \\
Total & 318 & 100 \\
& & \\
\hline
\end{tabular}




\begin{tabular}{|c|c|c|c|}
\hline \multirow[t]{6}{*}{2} & Age & & \\
\hline & 20-30 years & 65 & 20.4 \\
\hline & $31-40$ years & 183 & 57.5 \\
\hline & $41-50$ years & 62 & 19.5 \\
\hline & More than 50 & 8 & 2.5 \\
\hline & Total & 318 & 100 \\
\hline \multirow[t]{6}{*}{3} & Work experience & & \\
\hline & Less than 1 year & 2 & 0.6 \\
\hline & $1-5$ years & 165 & 51.9 \\
\hline & $6-10$ years & 75 & 23.6 \\
\hline & More than 10 & 76 & 23.9 \\
\hline & Total & 318 & 100.0 \\
\hline \multirow[t]{6}{*}{4} & Location of school & & \\
\hline & Central city & 75 & 23.6 \\
\hline & Suburb & 125 & 39.3 \\
\hline & Rural & 110 & 34.6 \\
\hline & No response & 8 & 2.5 \\
\hline & Total & 318 & 100 \\
\hline
\end{tabular}

Source: Survey data

\section{School library use}

The respondents were asked whether they used the library to obtain information that was relevant for teaching. Two hundred and seventy $(84.9 \%)$ respondents indicated that they used the library to obtain information to fulfill their information needs and 48 respondents $(15.1 \%)$ indicated that they did not use the library to fulfill their information needs. When the respondents were asked whether they met their information needs from the library, $80.8 \%$ mentioned that their information needs were fulfilled by the library while $11.3 \%$ mentioned that their needs were not fulfilled and $7.9 \%$ refrained from responding.

Respondents were again asked to mark the reasons for their school library use and the results are shown in Table 2 below. 
Table 2. Reasons for school library use*

\begin{tabular}{llrr}
\hline & \multicolumn{1}{c}{ Reason } & Frequency & Percentage \\
\hline $\mathbf{1}$ & Support own reading & 254 & 79.9 \\
$\mathbf{2}$ & Support class room teaching & 251 & 78.9 \\
$\mathbf{3}$ & Keep abreast with current & 247 & 77.7 \\
& information & & \\
$\mathbf{4}$ & Lesson preparation & 239 & 75.2 \\
$\mathbf{5}$ & Read newspapers/magazine & 234 & 73.6 \\
$\mathbf{6}$ & Use of reference books & 222 & 69.8 \\
$(\mathrm{~N}=318)$ & & \\
\hline
\end{tabular}

Source: Survey data *Note: Multiple responses allowed

As shown in the Table 2, the majority of the respondents used the school library to obtain information for their own reading, to get supplementary information for classroom teaching and to keep abreast with current information in their subject areas. More than $75 \%$ of the respondents used the library for lesson preparation followed by reading newspapers or magazines and for reference.

The respondents were asked to rate the level of adequacy of information resources available in the school library by using four scales namely "Very good", "Good", "Fair", and "Below standard". At the same time, they were asked to indicate how they access information available in the library and the action that they took if they did not meet their information needs from the library. Results are depicted in Table 3.

According to the Table 3, for more than $40 \%$ of the respondents, the information resources and facilities available at the school's library was "fair" followed by "good" (26\%), "below standard" (15.4\%), , and "very good" $(6.3 \%)$. 
Table 3. Descriptive statistics on library access and resource adequacy

\begin{tabular}{|c|c|c|c|}
\hline & $\begin{array}{c}\text { Library access and resource } \\
\text { adequacy }\end{array}$ & Frequency & Percentage \\
\hline & $\begin{array}{l}\text { Adequacy of library } \\
\text { resources }\end{array}$ & & \\
\hline 1 & Very Good & 20 & 6.3 \\
\hline 2 & Good & 83 & 26.1 \\
\hline 3 & Fair & 135 & 42.5 \\
\hline \multirow[t]{3}{*}{4} & Below Standard & 49 & 15.4 \\
\hline & No response & 31 & 9.7 \\
\hline & Access to the library* & & \\
\hline 1 & $\begin{array}{l}\text { Browse through the library } \\
\text { stock }\end{array}$ & 253 & 79.6 \\
\hline 2 & Seek help from library staff & 240 & 75.5 \\
\hline 3 & $\begin{array}{l}\text { Use the library catalogue } \\
\text { Action taken if not met } \\
\text { information needs* }\end{array}$ & 140 & 44.0 \\
\hline \multirow[t]{2}{*}{1} & Ask the officer in charge of the & & \\
\hline & library for assistance & 263 & 82.7 \\
\hline 2 & Seek help from the Internet & 263 & 82.7 \\
\hline 3 & Consult colleague teacher & 238 & 74.8 \\
\hline 4 & $\begin{array}{l}\text { Give up } \\
318)\end{array}$ & 14 & 4.4 \\
\hline
\end{tabular}

Source: Survey data * Note: Multiple responses allowed

With regarding to the access to the library, the majority of the respondents accessed by browsing the library stock $(79.6 \%)$, while $75.5 \%$ sought help from the library staff and only $44 \%$ of them used the library catalogue. It was further revealed that the majority $(83 \%)$ of respondents asked the officer in charge of the library for assistance or sought help from the internet to find information wherever they were not available at the school library. Of the respondents, $75 \%$ consulted colleague teachers whereas $4.4 \%$ gave up when their information needs were not met by the school library. (Table 3 ) 


\section{Frequency of library use}

The respondents were asked about the frequency of visit to their school library. More than one third of the respondents indicated that they visited the library weekly while $25.8 \%$ visited occasionally and $14.2 \%$ visited the library monthly and only $9.4 \%$ visited the library daily (Figure 1). As a whole, the results confirmed that a majority of the respondents had not been to their school libraries regularly.

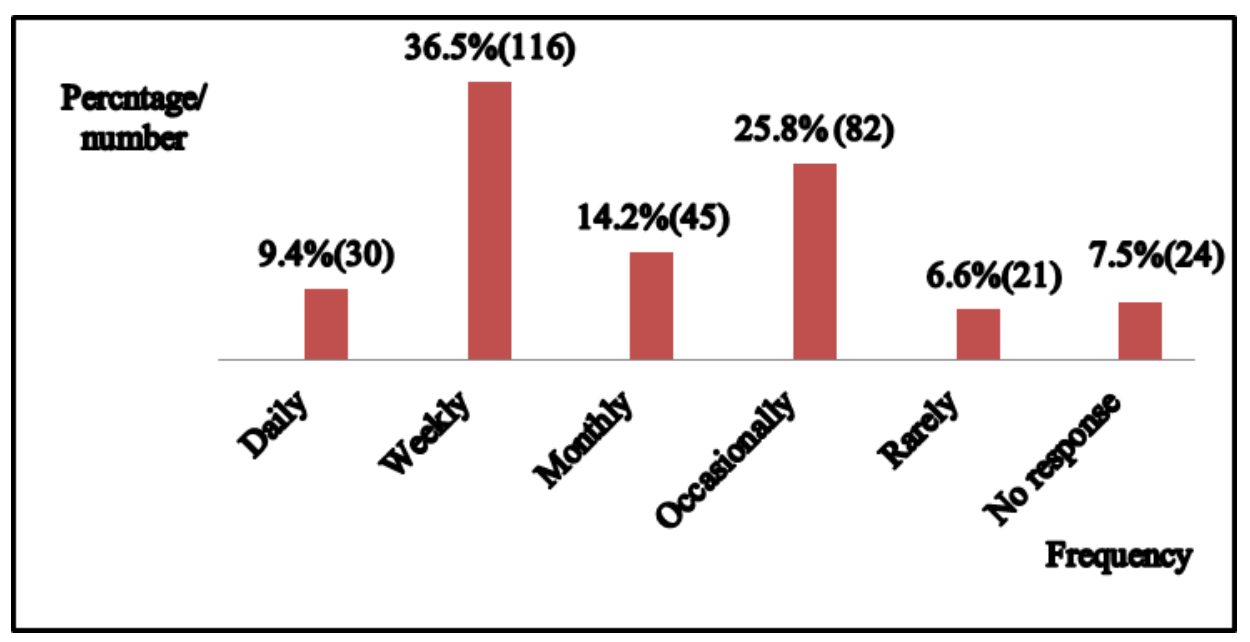

Figure 1. Frequency of school library use

\section{Library skills of school teachers}

The respondents were asked to rate how much they agreed on the given statements about library skills. In this regard, a five points scale was utilized (from 1 to 5, where 1 indicated "Strongly Disagree" and 5 indicated "Strongly Agree"). Library skill scale developed by Kampen (2004) was used to measure teachers' library skills after making necessary modifications to suite with the local context. Statements are listed in descending order according to the Likert mean scores.

It was found that $64 \%$ of the respondents were in the opinions that the school library should provide more services for the teachers, while $45 \%$ of the respondents felt that library was easy to use and $38 \%$ of the respondents had confident about their awareness on resources available in the library (Table 4). However, the majority (72\%) disagreed on the statement 
"availability of too many information sources in the library" while 55\% of the respondents disagreed on "adequacy of information training sessions offered by the library for the teachers" and $45 \%$ of the respondents disagreed on "comfortable use of computers in the library".

Table 4. Library skills and use scale

\begin{tabular}{|c|c|c|c|c|c|c|c|c|c|}
\hline & Statements & SDA & DA & $\mathbf{N U}$ & AG & SA & $\mathrm{RS}^{*}$ & MN* & SD* \\
\hline 1 & $\begin{array}{l}\text { The library should } \\
\text { provide more services } \\
\text { for teachers }\end{array}$ & $\begin{array}{r}6 \\
(2 \%)\end{array}$ & $\begin{array}{r}28 \\
(9 \%)\end{array}$ & $\begin{array}{l}59 \\
(19\end{array}$ & $\begin{array}{r}110 \\
(35 \%)\end{array}$ & $\begin{array}{r}93 \\
(29 \%)\end{array}$ & 296 & 3.86 & 1.029 \\
\hline 2 & $\begin{array}{l}\text { The library is easy to } \\
\text { use }\end{array}$ & $\begin{array}{r}25 \\
(8 \%)\end{array}$ & $\begin{array}{r}19 \\
(6 \%)\end{array}$ & $\begin{array}{r}98 \\
(31 \%)\end{array}$ & $\begin{array}{r}122 \\
(38 \%)\end{array}$ & $\begin{array}{r}21 \\
(7 \%)\end{array}$ & 285 & 3.33 & 1.016 \\
\hline 3 & $\begin{array}{l}\text { I know what resources } \\
\text { are available in the } \\
\text { library }\end{array}$ & $\begin{array}{r}18 \\
(6 \%)\end{array}$ & $\begin{array}{r}32 \\
(10 \%)\end{array}$ & $\begin{array}{r}132 \\
(42 \%)\end{array}$ & $\begin{array}{r}95 \\
(30 \%)\end{array}$ & $\begin{array}{r}25 \\
(8 \%)\end{array}$ & 302 & 3.25 & .963 \\
\hline 4 & $\begin{array}{l}\text { I can usually find the } \\
\text { resources I need in the } \\
\text { library }\end{array}$ & $\begin{array}{r}32 \\
(10 \%)\end{array}$ & $\begin{array}{r}32 \\
(10 \%)\end{array}$ & $\begin{array}{r}155 \\
(51 \%)\end{array}$ & $\begin{array}{r}69 \\
(23 \%)\end{array}$ & $\begin{array}{r}15 \\
(6 \%)\end{array}$ & 303 & 3.01 & .978 \\
\hline 5 & $\begin{array}{l}\text { I think my ability to } \\
\text { use the library has had } \\
\text { a negative effect on } \\
\text { my teaching }\end{array}$ & $\begin{array}{r}161 \\
(51 \%)\end{array}$ & $\begin{array}{r}94 \\
(32 \%)\end{array}$ & $\begin{array}{r}18 \\
(6 \%)\end{array}$ & $\begin{array}{r}11 \\
(4 \%)\end{array}$ & $\begin{array}{r}9 \\
(3 \%)\end{array}$ & 293 & 3.01 & .968 \\
\hline 6 & $\begin{array}{l}\text { My knowledge of the } \\
\text { library is limited to my } \\
\text { area of interest }\end{array}$ & $\begin{array}{r}37 \\
(12 \%)\end{array}$ & $\begin{array}{r}42 \\
(13 \%)\end{array}$ & $\begin{array}{r}145 \\
(46 \%)\end{array}$ & $\begin{array}{r}61 \\
(19 \%)\end{array}$ & $\begin{array}{r}18 \\
(6 \%)\end{array}$ & 303 & 2.94 & 1.032 \\
\hline 7 & $\begin{array}{l}\text { I am uncomfortable } \\
\text { using the library } \\
\text { catalogue }\end{array}$ & $\begin{array}{r}29 \\
(9 \%)\end{array}$ & $\begin{array}{r}69 \\
(22 \%)\end{array}$ & $\begin{array}{r}112 \\
(35 \%)\end{array}$ & $\begin{array}{r}80 \\
(25 \%)\end{array}$ & $\begin{array}{r}12 \\
(4 \%)\end{array}$ & 302 & 2.92 & 1.017 \\
\hline 8 & $\begin{array}{l}\text { It is difficult to locate } \\
\text { materials I need in the } \\
\text { library }\end{array}$ & $\begin{array}{r}31 \\
(10 \%)\end{array}$ & $\begin{array}{r}97 \\
(31 \%)\end{array}$ & $\begin{array}{r}90 \\
(28 \%)\end{array}$ & $\begin{array}{r}46 \\
(14 \%)\end{array}$ & $\begin{array}{r}35 \\
(11 \%)\end{array}$ & 299 & 2.86 & 1.160 \\
\hline 9 & $\begin{array}{l}\text { The library's resources } \\
\text { for my area of interest } \\
\text { are satisfactory }\end{array}$ & $\begin{array}{r}41 \\
(13 \%)\end{array}$ & $\begin{array}{r}70 \\
(22 \%)\end{array}$ & $\begin{array}{r}109 \\
(34 \%)\end{array}$ & $\begin{array}{r}68 \\
(21 \%)\end{array}$ & $\begin{array}{r}12 \\
(4 \%)\end{array}$ & 300 & 2.80 & 1.063 \\
\hline 10 & $\begin{array}{l}\text { I am comfortable } \\
\text { using the computers } \\
\text { inside the library }\end{array}$ & $\begin{array}{r}91 \\
(27 \%)\end{array}$ & $\begin{array}{r}56 \\
(18 \%)\end{array}$ & $\begin{array}{r}64 \\
(20 \%)\end{array}$ & $\begin{array}{r}29 \\
(9 \%)\end{array}$ & $\begin{array}{r}27 \\
(8.5 \%)\end{array}$ & 267 & 2.42 & 1.325 \\
\hline 11 & $\begin{array}{l}\text { The library offers } \\
\text { enough information } \\
\text { skills training sessions } \\
\text { for teachers }\end{array}$ & $\begin{array}{r}60 \\
(19 \%)\end{array}$ & $\begin{array}{r}116 \\
(36 \%)\end{array}$ & $\begin{array}{r}89 \\
(28 \%)\end{array}$ & $\begin{array}{r}29 \\
(9 \%)\end{array}$ & $\begin{array}{r}8 \\
(2.5 \%)\end{array}$ & 302 & 2.37 & .992 \\
\hline 12 & $\begin{array}{l}\text { There are too many } \\
\text { possible sources of } \\
\text { information }\end{array}$ & $\begin{array}{r}113 \\
(36 \%)\end{array}$ & $\begin{array}{r}113 \\
(36 \%)\end{array}$ & $\begin{array}{r}40 \\
(13 \%)\end{array}$ & $\begin{array}{r}21 \\
(7 \%)\end{array}$ & $\begin{array}{r}8 \\
(2.5 \%)\end{array}$ & 295 & 1.98 & 1.025 \\
\hline
\end{tabular}

$\mathrm{SDA}=$ Strongly Disagree: DA= Disagree: $\mathrm{NU}=$ Neutral; $\mathrm{AG}=$ Agree; $\mathrm{SA}=$ Strongly Agree, $R S^{*}=$ Number of Responses: $M N^{*}=$ Mean Score; $S D^{*}=$ Standard Deviation 
These results gave an insight that the teachers had the skills on the use of libraries easily while they were aware about the available library resources. At the same time they urged more library services for the teachers. On the other hand, they felt that libraries lack information sources and they urged from the library to offer more information skills training sessions for them.

\section{Satisfaction towards available library services and resources}

The respondents were asked to rate about their level of satisfaction and it was found that more than half of the respondents agreed on the statement "library arrangement is good and relevant information sources could be easily located" while less than half of the respondents agreed on "helpfulness of user awareness programs conducted by the library" (47\%) and "helpfulness of library staff" (46\%) with the highest mean score values. However, there were a substantial proportion of respondents who were uncertain $(43 \%)$ or dissatisfied $(38 \%)$ on library resources available in the subjects that they taught in schools and $45 \%$ of the respondents indicated their disagreement on the statement, "library has current and updated collection".

Table 5. Satisfaction with library services and resources

\begin{tabular}{|c|c|c|c|c|c|c|c|c|c|}
\hline & Statements & SDA & DA & $\mathbf{N U}$ & AG & $\mathbf{S A}$ & $\mathbf{R S} *$ & $\mathbf{M N} *$ & SD* \\
\hline \multirow[t]{2}{*}{1} & Library user awareness & 22 & 36 & 97 & 92 & 46 & 293 & 3.35 & 1.115 \\
\hline & programs are helpful & $(8 \%)$ & $(12 \%)$ & $(33 \%)$ & $(31 \%)$ & $(16 \%)$ & & & \\
\hline \multirow[t]{2}{*}{2} & Staff in the library is & 31 & 35 & 91 & 90 & 44 & 291 & 3.28 & 1.178 \\
\hline & helpful & $(11 \%)$ & $(12 \%)$ & $(31 \%)$ & $(31 \%)$ & $(15 \%)$ & & & \\
\hline \multirow[t]{2}{*}{3} & Library arrangement is & 40 & 49 & 68 & 96 & 45 & 298 & 3.19 & 1.263 \\
\hline & $\begin{array}{l}\text { good and relevant } \\
\text { information sources } \\
\text { could be easily located }\end{array}$ & $(13 \%)$ & $(16 \%)$ & $(23 \%)$ & $(32 \%)$ & $(20 \%)$ & & & \\
\hline \multirow[t]{2}{*}{4} & Library catalogue & 58 & 44 & 82 & 78 & 34 & 296 & 2.95 & 1.288 \\
\hline & $\begin{array}{l}\text { provide easy access to } \\
\text { library resources }\end{array}$ & $(20 \%)$ & $(15 \%)$ & $(28 \%)$ & $(26 \%)$ & $(11 \%)$ & & & \\
\hline \multirow[t]{2}{*}{5} & I am satisfied with & 45 & 68 & 128 & 48 & 10 & 299 & 2.70 & 1.018 \\
\hline & $\begin{array}{l}\text { resources available in } \\
\text { the subjects that I } \\
\text { taught }\end{array}$ & $(15 \%)$ & $(23 \%)$ & $(43 \%)$ & $(16 \%)$ & $(3 \%)$ & & & \\
\hline \multirow[t]{2}{*}{6} & Library has current and & 37 & 97 & 98 & 49 & 17 & 298 & 2.70 & 1.064 \\
\hline & updated collection & $(12 \%)$ & $(33 \%)$ & $(33 \%)$ & $(16 \%)$ & $(6 \%)$ & & & \\
\hline
\end{tabular}

$\overline{\mathrm{SDA}}=$ Strongly Disagree; DA= Disagree; NU= Neutral; AG= Agree; SA= Strongly Agree; $R S=$ Number of Responses: $M N=$ Mean Score; $S D=$ Standard Deviation 
The results revealed that a substantial proportion of respondents were satisfied about library services particularly on user awareness programs, staff assistance and library arrangement but they were not satisfied about the availability of current and updated resources in their subject fields.

\section{Problems faced in using school libraries}

The respondents were asked to indicate the types of problems they encountered in using their school libraries. The top most twelve problems that encountered by the teachers in using the library were listed. From Table 6 , it can be seen that the majority had faced some problems such as the lack of relevant materials in the library, lack of information on available resources, non-availability of e-resources and outdated library collections.

\section{Table 6. Descriptive statistics of library related barriers}

\begin{tabular}{|c|c|c|c|}
\hline & Barrier/ Problem/ Difficulty & Frequency & Percentage \\
\hline 1 & $\begin{array}{l}\text { Lack of relevant materials in the school's } \\
\text { library }\end{array}$ & 274 & 86.2 \\
\hline 2 & $\begin{array}{l}\text { Lack of information about available } \\
\text { sources }\end{array}$ & 254 & 79.9 \\
\hline 3 & $\begin{array}{l}\text { Non availability of electronic resource } \\
\text { (e-journals ) }\end{array}$ & 248 & 78.0 \\
\hline 4 & Required materials are not available & 244 & 76.7 \\
\hline 5 & $\begin{array}{l}\text { Latest information sources are not } \\
\text { available/ outdated material }\end{array}$ & 240 & 75.5 \\
\hline 6 & $\begin{array}{l}\text { Difficult in finding from existing } \\
\text { resources }\end{array}$ & 215 & 67.6 \\
\hline 7 & $\begin{array}{l}\text { Information is scattered in too many } \\
\text { sources }\end{array}$ & 164 & 51.6 \\
\hline 8 & Lack of support from library staff & 141 & 44.3 \\
\hline 9 & $\begin{array}{l}\text { Library staff is incompetent or not } \\
\text { well-trained }\end{array}$ & 140 & 44.0 \\
\hline 11 & Lack of knowledge in using the library & 121 & 38.1 \\
\hline
\end{tabular}

These results were consistent with the study conducted by Williams \& Coles (2007) who found that the inadequate library facilities, unavailability and inability to locate up- to-date information as problems faced by the teachers in using school libraries. These findings are not different from the studies 
conducted by Johnson (2000) and Tachie-Donkor, and Dadzie (2017) who concluded that teachers did not find relevant materials from their school libraries.

\section{Association of library awareness skills and variables}

In order to find out whether any associations between teachers' library awareness skills and four selected variables such as gender, age, experience and school location, an exploratory factor analysis was conducted. The same library skill scale developed by Kampen (2004) was used and it was tested for its reliability, and the Cronbach's alpha value was 0.701 for the overall scale.

\section{Factor analysis of the library skills}

The method of list wise deletion was used to exclude respondents who did not check any of the items from the factor analysis. Principal component analysis was employed to extract factors, and two factors were retained by a Scree test and Kaiser's criterion (eigenvalue>1). Statements with the highest loading with a particular factor were grouped under that factor, and those that correlated less than 0.5 with a factor were not loaded.

The Kaiser-Meyer-Olkin (KMO) measure of sampling adequacy is a test of the amount of variance within the data that could be explained by factors. As a measure of factorability a $\mathrm{KMO}$ value of 0.5 is poor; 0.6 is acceptable; a value closer to 1 is better, and the Bartlett's test indicates that the data is probably factorable if $\mathrm{p}<.50$ (Brace, Kemp \& Snelgar, 2006). Data from the library awareness scale was analysed by means of a principal component analysis, with varimax rotation. The various indicators of factorability were very good, and the residuals indicate that the solution was a good one. Three components with an eigenvalue $>1.0$ were found; items with the highest loading were chosen for each factor (see Tables 7 and 8).

A three factor solution accounted for $54.325 \%$ of the total variance and three components were elicited (see Table 7). These three factors were grouped into three broad themes: The components (factors) can be thought of as representing three main themes: component 1- related to awareness of what the library offers and its use; component 2- related to attributes towards 
using the library and component 3- related to the services offered by the library.

\section{Table 7. Total variance explained}

\begin{tabular}{cccc}
\hline Factor & Cumulative variance & Total variance & Eigenvalue \\
\hline 1 & 26.069 & 26.069 & 3.128 \\
2 & 42.236 & 16.167 & 1.940 \\
3 & 54.325 & 12.089 & 1.451 \\
\hline
\end{tabular}

Source: Survey data

\section{Table 8. Factor loadings for library awareness scale}

\begin{tabular}{|c|c|c|c|c|}
\hline \multirow[t]{2}{*}{$\mathbf{s} / \mathbf{n}$} & \multirow[t]{2}{*}{ Statement } & \multicolumn{3}{|c|}{ Component } \\
\hline & & 1 & 2 & 3 \\
\hline 1 & I know what resources are available in the library & .750 & & \\
\hline 2 & The library is easy to use & .744 & & \\
\hline 3 & $\begin{array}{l}\text { The library's resources in my area of interest are } \\
\text { satisfactory }\end{array}$ & 649 & & \\
\hline 4 & $\begin{array}{l}\text { I can usually find the resources I need in the } \\
\text { library }\end{array}$ & .629 & & \\
\hline 5 & $\begin{array}{l}\text { The library offers enough information skills } \\
\text { training sessions for teachers }\end{array}$ & .497 & & \\
\hline 6 & $\begin{array}{l}\text { I am comfortable in using the computers inside } \\
\text { the library }\end{array}$ & .437 & & \\
\hline 7 & $\begin{array}{l}\text { I think that my ability to use the library had a } \\
\text { negative effect on my teaching }\end{array}$ & & 695 & \\
\hline 8 & $\begin{array}{l}\text { There are too many possible sources of } \\
\text { information }\end{array}$ & & 691 & \\
\hline 9 & $\begin{array}{l}\text { My knowledge of the library is limited to my } \\
\text { area of interest }\end{array}$ & & 639 & \\
\hline 10 & I am uncomfortable using the library catalogue & & .318 & \\
\hline 11 & $\begin{array}{l}\text { The library should provide more services for } \\
\text { teachers }\end{array}$ & & & .752 \\
\hline 12 & $\begin{array}{l}\text { It is difficult to locate materials I need in the } \\
\text { library }\end{array}$ & & & .665 \\
\hline
\end{tabular}

Source: Survey data

The factor one consisted of six items with factor loading $>.3$, which accounted for $26.069 \%$ of the total variance. The items with highest loadings in this factor were related to the respondents' awareness of library resources and the easiness of library to use.

Factor Two was named "attributes towards using the library ", and it accounted for $16.167 \%$ of the total variance, four items with high loading. 
Items in this factor addressed ability to use the library has had a negative effect on teaching and the perception of the availability of too many possible sources in the library.

Factor three named "services offered by the library" and it accounted for $12.089 \%$ of the total variance, two items with loading. The item with highest loadings in this factor was related to the perception of the library to provide more services for teachers. (See Tables 7 and 8) These factors will be used for the regression analysis and verifying the study's model.

Regression analysis of the library skills

Logistic regression analysis was conducted using SPSS version 21.0 to identify the predictors of the library skills of the school teachers. The goal of this analysis was to study the associations between each dependent variable representing key factors of library skills and four independent variables such as gender, age, experience and location of school. In this section, a series of ordinal logistic regressions were run for achieving the objectives of the study (Objective no.5).

Table 9. Logistic regression key results of "library should provide more services for teachers"

\begin{tabular}{|c|c|c|c|c|c|c|}
\hline \multirow[t]{2}{*}{$\begin{array}{l}\text { Variables in } \\
\text { equation }\end{array}$} & \multirow[t]{2}{*}{ B } & \multirow[t]{2}{*}{$\mathbf{S E}$} & \multirow[t]{2}{*}{ Sig } & \multirow[t]{2}{*}{$\begin{array}{r}\text { Exp } \\
\text { (B) }\end{array}$} & \multicolumn{2}{|c|}{$\begin{array}{c}95 \% \text { C. I. for } \\
\text { OR }\end{array}$} \\
\hline & & & & & Lower & Upper \\
\hline Gender (2) & -.295 & .463 & .523 & .744 & .301 & 1.843 \\
\hline Age & .330 & .310 & .287 & 1.391 & .758 & 2.554 \\
\hline Experience & -.240 & .242 & .322 & .787 & .490 & 1.264 \\
\hline Location & .167 & .194 & .391 & 1.181 & .807 & 1.729 \\
\hline Constant & .323 & 1.242 & .795 & & & \\
\hline
\end{tabular}

Source: Survey data

Firstly a logistic regression was run for the highest loading factor of the library skill scale that is the library should provide more services for teachers. Three hundred and eighteen cases were analyzed and the full model significantly predicted " library should provide more services for teachers" (omnibus chi-square $\mathrm{X}^{2}=26.856, \mathrm{df}=16, \mathrm{p}=0.043$ ). Overall, $43.4 \%$ of predictions were accurate. Table 9 gives a detailed description of the values calculated for the independent variables entered in the last step of the 
regression stepwise forward method. As it can be gleaned in Table 9, there were no variables found to be statistically significant.

\section{Conclusion}

As emerged from the findings, teachers top most reason to use school library was to obtain information for their own reading. The next most important reasons to use school library were to obtain information to supplement classroom teaching and to keep abreast with current information in subject areas related to their teaching purposes. The results revealed that most of the teachers apprehend that the library should provide more services for teachers and most of them were uncertain about their ability of using the library easily. Moreover, the results showed that most of the teachers agreed that user awareness programs conducted by the library were very helpful and they were satisfied about the helpfulness of library staff too. The results further revealed that the lack of relevant materials in the school library, lack of information about available sources, unavailability of electronic resources, outdated library materials, difficulty in finding resources from existing collection as main problems encountered by the teachers when using school libraries. Furthermore, it was found that there was no association between library awareness skills of the teachers and the four variables such as gender, age, work experience and school location.

\section{Recommendations}

Based on the findings of the study, the following recommendations are made;

i. Upgrading school libraries with necessary information resources and services to develop knowledge and skills of teachers.

ii. Providing more up-to- date information materials relevant to school teaching and learning.

iii. Conducting information literacy skills courses for teachers to make their use of library more effective and to enable them to transfer these skills to the learners.

iv. Developing innovative marketing strategies in libraries to promote services that offer for school teachers.

\section{References}

Asselin, M. \& Doiron, R. (2003). Whither they go: an analysis of the inclusion of school library programs and services in the preparation of pre-service teachers in Canadian universities. Behavioral \& Social Sciences Librarian, 22 (1), 19-32. 
Brace, N., Kemp, R. and Snelgar, R. (2006). SPSS for psychologists: A guide to data analysis using SPSS for Windows (3rd ed.). Palgrave: Macmillan.

Chartered Institute of Library and Information Professionals (CILIP) (2004). Information literacy: definition. Retrieved form: https://www.cilip.org.uk/news/421972/ What-is-information-literacy.htm

De la Vega, A. \& Puente, R. T. (2010). Availability and use of printed, audio-visual and electronic information by high school teachers of communication and social sciences in Public educational institutions in Peru. Libri, 60 (4), 306-320.

Hiller, S. (2002). How Different Are They? A Comparison by academic area of library use, priorities, and information needs at the University of Washington. http://www.istl.org/02-winter/article1.html

Johnson, H. (2000). Introduction in: seven pillars of wisdom? Good practice in information literacy skills development. Proceedings of a conference held at the University of Warwick, June 6-7 2000, S. Corrall and H. Hathaway (Ed.). London: SCONUL, 3-4.

Kampen, D. (2004). Development and validation of the multidimensional library anxiety Scale. College \& Research Libraries, 4(1), 28-34.

Korobili S., Malliari A., Daniilidou E., \& Christodoulou G. (2011) A paradigm of information literacy for Greek high school teachers, Journal of Librarianship and Information Science, 43(2), 78-87.

Krejcie, R. V. \& Morgan, D. W. (1970). Determining sample size for research activities. Educational and Psychological Measurement, 30 (3), 607-610.

Martell, C. (2008). The Absent User: Physical Use of Academic Library Collections and Services Continues to Decline 1995-2006. The Journal of Academic Librarianship, 34(5), 400-407.

McLelland, D. \& Crawford, J. (2004). The Drum chapel Project: a study of ICT usage by school pupils and teachers in a secondary school in a deprived area of Glasgow. Journal of Librarianship and Information Science, 36(2), 55-67. 
Mokhtar, I .A. and Majid, S. (2005) Use of school libraries by teachers in Singapore schools, Library Review, 54 (2), 108-118

Önal, H.I. (2009). IFLA/UNESCO school library manifesto for creating one world: Germany, Iran and Turkey in comparative perspective. Libri, 59(1), 45-54.

Rathnayake, S. (2013) An analytical study on library usage of school teachers for teaching process. Proceedings of research conference on information literacy, Colombo: National Institute of Library and Information Science, 112-122.

Sim, M.L. (2001), The role of a media resource library in preparing students for independent thinking and lifelong learning, [unpublished Master's dissertation], Nanyang Technological University, Singapore.

Song, Y. (2009). Designing library services based on user needs: new opportunities to reposition the library. Retrieved from https://www.ifla.org/past-wlic/2009/202-song-en.pdf

Department of Census and Statistics (2017). Statistical Abstract, Retrieved from http://www.statistics.gov.lk/Abstract2017/index.asp

Tan, C.N. (2003). School media resource libraries in Singapore: an assessment and potential developments, [unpublished Master's dissertation], Nanyang Technological University, Singapore.

Tachie-Donkor,G. \& Dadzie, P. (2017). Developing teachers' information literacy capabilities in secondary schools in Ghana: A comparative study of two best schools in the central region, Library Philosophy and Practice(e-journal). $1573 . \quad$ Retrieved from http://digitalcommons.unl.edu/libphilprac/1573

Wessels, N. \& Mnkeni-Saurombe, N. (2012). Teachers' use of a school library in a South African township school: closing the literacy gap, $S A$ Jnl Libs \& Info Sci , 78(1), 23-34.

Williams, D. \& Coles, L. (2007). Evidence-based practice in teaching: an information perspective. Journal of Documentation, 63(6), 812-835. 